\title{
SUBTILISIN INHIBITOR FROM SEEDS OF BROAD BEAN (VICIA FABA); PURIFICATION, AMINO ACID SEQUENCE AND SPECIFICITY OF INHIBITION
}

\author{
by \\ IB SVENDSEN
}

Carlsberg Laboratory, Department of Chemistry

Gamle Carlsberg Vej 10, DK-2500 Copenhagen Valby

and

JØRN HEJGAARD and JAYASING K. CHAVAN "

Department of Biochemistry and Nutrition

Technical University of Denmark, DK-2800 Lyngby

"Present address: Food Science and Technology,

Mahatma Phule Agricultural University, Rahuri 413 722, M.S., India.

\begin{abstract}
Keywords: Serine protease inhibitors, amino acid composition, amino acid sequence, homology, active site, potato inhibitor I family
\end{abstract}

\begin{abstract}
A potent inhibitor of microbial serine proteases, including subtilisin, has been purified 1100 -fold from seeds of broad bean (Vicia faba, cv. Kleine Thüringer). Chymotrypsin and trypsin were not inhibited, but a weak "temporary" inhibition of pancreas elastase was observed. The preparation of pure inhibitor contained one major molecular form with a blocked $\mathrm{N}$-terminal $(\mathrm{MW} \sim 10,000, \mathrm{pI} \sim 4.8)$ and a minor form $(<10 \%)$ with slightly lower $\mathrm{MW}$ and $\mathrm{pl}-5.0$. About $80 \%$ of the amino acid sequence of the major form was determined by automatic Edman degradation of a cyanogen bromide fragment and tryptic peptides. The inhibitor is homologous with barley, potato and leech inhibitors of the "potato inhibitor I family" (36-56\% of the amino acid residues in identical positions). Cleavage studies suggest one enzyme inhibitory site at an Ala-Asp bond.
\end{abstract}

\section{INTRODUCTION}

Leguminous seed inhibitors of trypsin and chymotrypsin, classified in the "Bowman-Birk and Kunitz plant inhibitor families" (7), are among the best characterized plant proteins. Isoelectric focusing has, however, shown that all legume seeds tested also contain significant amounts of one or two subtilisin inhibitors with

Abbreviations: APNE = N-acetyl-D,L-phenylalanine-2-naphtyl ester; BAPA = N-Benzoyl-L-arginine-p-nitroanilide; $\mathrm{CI}-1$ and $\mathrm{CI}-2$ : Chymotrypsin inhibitor 1 and 2 from barley $(1,16)$; EDTA = Ethylenediamine tetraacetate; GPPA $=$ N-glutaryl-L-phenylalanyl p-nitroanilide; HPLC = High performance liquid chromatography; IEF $=$ Isoelectric focusing; LIE = Leech inhibitor eglin (13); PAGE = Polyacrylamide gel electrophoresis; PI-I = Potato inhibitor I (11, 12); PTH = Phenylthiohydantoin; SAAAPA = N-succinyl-L-alanyl-L-alanyl-L-alanine-p-nitroanilide; SDS = Sodium dodecylsulphate; VSI = Vicia subtilisin inhibitor; ZGGLPA = Carbobenzoxy-glycyl-glycyl-Lleucine-p-nitroanilide; ZPNE = Carbobenzoxy-L-phenylalanine-2-naphthylester. 
pI 4.5 - 6, which are not related to any of these two families of homologous inhibitors (2). Legume subtilisin inhibitors have, so far, been purified from seeds of black bean (Phaseolus vulgaris) (14) and cowpea (Vigna unguiculata) $(19,20)$. Characterization of the Phaseolus inhibitor with respect to disulphide bridges and specificity (15) indicated relations to the "Streptomyces subtilisin inhibitor family" (7).

In the present study a subtilisin inhibitor was isolated from broad bean (Vicia faba). Characterization, including sequence studies, clearly shows that this legume inhibitor is a member of the "potato inhibitor I family" (7). The family includes a number of homologous inhibitors from higher plants (16) and one from a lower animal, the leech (13). These inhibitors are not functionally dependent on the presence of disulphide bridges in their structure (16). The abbreviation VSI is used for the Vicia subtilisin inhibitor, although characterization of the specificity also showed a weak inhibition of pancreas elastase.

\section{MATERIALS AND METHODS}

\subsection{Materials}

Bovine trypsin, bovine chymotrypsin, subtilisin Carlsberg, subtilisin Novo and Bacillus pulimus protease were obtained from Novo Industries, Bagsværd, Denmark, Aspergillus oryzae protease from Sigma, St. Louis, USA, and porcine pancreas elastase from Boehringer, Mannheim, GFR. The substrates GPPA and BAPA were from Merck, Darmstadt, GFR, ZPNE from ICN, Cleveland, Ohio, USA, ZGGLPA from Serva, Heidelberg, GFR, SAAAPA from Sigma, St. Louis, USA, and APNE from Bachem, Switzerland. Zwittergent 3-12 was obtained from Calbiochem, Cal., USA. Sephadex G75 and DEAE-Sephadex A50 were products of Pharmacia, Uppsala, Sweden. All chemicals used in the sequencer were from Rathburn, Walkerburn, U.K. except ethylacetate which was a Merck product and Polybrene which was from Pierce, Rochford, USA.

\subsection{Protease inhibitor assays}

During purification inhibition of subtilisin was monitored at $25^{\circ} \mathrm{C}$ by fluorescence spectro- photometry using a cylindrical flow cuvette (Uvicord II, LKB, Sweden) mounted in a Perkin-Elmer 204 fluorescence spectrophotometer. About $0.5 \mu \mathrm{g}$ subtilisin Carlsberg was preincubated for $5 \mathrm{~min}$ with appropriately diluted inhibitor solution in a final volume of 100 $\mu \mathrm{l} 50$ mM-phosphate buffer, $\mathrm{pH}$ 7.8. A solution of substrate in the same buffer $(400 \mu \mathrm{l})$ was added to give a final concentration of $75 \mu \mathrm{M}$ ZPNE dissolved by the presence of $9 \%$ dimethylformamide and $0.2 \%$ SDS. The mixture was drawn into the cuvette, and increase in fluorescence was registered continuously using $\lambda_{\text {rxci. }}=$ $330 \mathrm{~nm}$ and $\lambda_{\text {anal. }}=420 \mathrm{~nm}$. One inhibitor unit was defined as the calculated amount of inhibitor which inactivated $1 \mathrm{mg}$ of subtilisin preparation in the assay.

For the specificity studies, inhibition of serine proteases was determined spectrophotometrically at $410 \mathrm{~nm}$ and $25^{\circ} \mathrm{C}$ in $1 \mathrm{ml} 50 \mathrm{~mm}$-Tris$\mathrm{HCl}, \mathrm{pH} 8.0$ after 5 min preincubation of enzyme with inhibitor. Residual activity was measured continuously with the following substrates: subtilisin Carlsberg, subtilisin Novo, Bacillus pumilus protease and Aspergillus oryzae protease with $0.18 \mathrm{~mm}$-ZGGLPA, porcine pancreas elastase with $0.1 \mathrm{mM}$-SAAAPA, bovine chymotrypsin with $0.83 \mathrm{~mm}-\mathrm{GPPA}$, and bovine trypsin with $0.5 \mathrm{mM}$-BAPA.

All enzymes were dissolved in $10 \mathrm{~mm}$-sodium

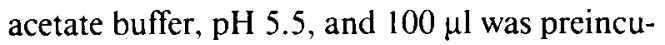
bated with $300 \mu \mathrm{l}$ inhibitor solution. The most reproducible results were obtained when the final inhibitor dilutions were made with $0.1 \%$ Zwittergent 3-12. All assays with ZGGLPA were made in the presence of $9 \%$ acetonitrile to keep the substrate dissolved (9). Assays with the technical grade preparations of proteases from Aspergillus oryzae and Bacillus pumilus were made in the presence of $10 \mathrm{~mm}$-EDTA, an efficient inhibitor of microbial neutral proteases (10).

\subsection{Extraction and $\left(\mathrm{NH}_{4}\right)_{2} \mathrm{SO}_{4}$ precipitation}

Seeds of broad bean (Vicia faba, cv. Kleine Thuringer) were dehulled manually and ground to a fine flour in a Udy cyclone mill. The flour $(250 \mathrm{~g})$ was stirred vigorously with water $(2,500$ $\mathrm{ml}$ ) for 2 hours at $20^{\circ} \mathrm{C}$, and the extract was 
isolated by centrifugation at $10000 \mathrm{G}$ for 20 min. All subsequent purification steps were performed at $2-4{ }^{\circ} \mathrm{C}$. After adjustment to $40 \%$ saturation with ammonium sulfate the extract was stirred for 2 hours and centrifuged. The concentration of ammonium sulfate in the supernatant solution was increased to $60 \%$ saturation, and precipitation of the inhibitor was made overnight. After centrifugation the precipitate was dissolved in $200 \mathrm{ml}$ water and dialyzed against several changes of water followed by 50 mM-Tris-HCl buffer, $\mathrm{pH} 8.5$.

\subsection{Chromatography}

\subsubsection{Anion exchange, $p H 8.5$}

After centrifugation the crude inhibitor preparation (section 2.3) was mixed with $200 \mathrm{ml}$ DEAE-Sephadex A 50, which had been swelled and equilibrated in $50 \mathrm{mM}$-Tris- $\mathrm{HCl}$ buffer, $\mathrm{pH}$ 8.5. After gentle shaking overnight the gel was washed with the same buffer on a Büchner funnel, packed in a $2.5 \times 30 \mathrm{~cm}$ column, and the inhibitor was eluted at a rate of $25 \mathrm{ml} \times \mathrm{h}^{-1}$ with 1 litre of a $0-0.5 \mathrm{M}$ linear gradient of $\mathrm{NaCl}$ in the buffer. After inhibitor assays, pooled fractions were dialyzed against water and freeze-dried.

\subsubsection{Gelfiltration, Sephadex $G 50$}

The freeze-dried material from anion exchange (section 2.4.1) was dissolved in $10 \mathrm{ml} 25$ mM-phosphate buffer, $\mathrm{pH} 7.5$, and applied to a $2.5 \times 80 \mathrm{~cm}$ column of Sephadex G50. Proteins were eluted with the same buffer at a flow rate of

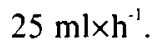

\subsubsection{Anion exchange, $p H 7.5$}

Pooled fractions from gel filtration (section 2.4.2) were applied directly to a $1.5 \times 30 \mathrm{~cm}$ column of DEAE-Sephadex. After washing with 25 mM-phosphate buffer, $\mathrm{pH} 7.5$, a $0-0.2 \mathrm{M}$ linear gradient of $\mathrm{NaCl}$ in the buffer was applied at a rate of $5 \mathrm{ml} \times \mathrm{h}^{-1}$. Fractions $(3 \mathrm{ml})$ containing inhibitor activity were pooled and freeze-dried after desalting on a column of Sephadex G25.

\subsubsection{Gel filtration, Sephadex G75}

Freeze-dried inhibitor from anion exchange, $\mathrm{pH} 7.5$ (section 2.4.3) was dissolved in 50 mM-phosphate buffer, $\mathrm{pH} 6.1$, containing 0.5 $\mathrm{M}-\mathrm{NaCl}(2 \mathrm{mg} / \mathrm{ml})$. Two $\mathrm{ml}$ portions of this solution were applied to a $0.9 \times 120 \mathrm{~cm}$ column of Sephadex G75, and the inhibitor was eluted with the same buffer at a flow rate of $10 \mathrm{ml} \times \mathrm{h}^{-1}$ and $2 \mathrm{ml}$ fractions were collected. Standardization under the same experimental conditions was made with a mixture of ovalbumin (MW 43,000), carbonic anhydrase (MW 30,000), cytochrome C (MW 12,500), and aprotinin (MW 6,500).

\subsection{Electrophoresis}

IEF was made with $2 \%$ Ampholine, $\mathrm{pH} 3-10$ (LKB), at $25^{\circ} \mathrm{C}$ in $74 \times 2.7 \mathrm{~mm}$ polyacrylamide gel rods and staining for inhibition of subtilisin, trypsin and chymotrypsin was made with the chromogenic substrate APNE, as described in detail previously (2). SDS-PAGE was made in $180 \times 180 \times 1 \mathrm{~mm}$ gel slabs $(1,16)$.

\subsection{Amino acid analysis}

Acid hydrolysis in $5.7 \mathrm{~N}-\mathrm{HCl}$ was made in evacuated sealed tubes for 24 hours and the analysis performed on a Durrum D500 amino acid analyser. Performic acid oxidation was done according to HiRs (4) to check for the presence of cystein or cystine.

\subsection{Amino acid sequence determination}

Determination of the amino acid sequences was performed as described previously (5) in a Beckman liquid phase sequenator, model 830 . In most cases Polybrene was added together with the sample. Identification of the PTH-amino acids was made by HPLC on a Hewlett-Packard chromatograph, model 1083B as described by SVENDSEN et al. (18).

\subsection{Cleavage with cyanogen bromide}

Six $\mathrm{mg}$ of inhibitor was dissolved in $600 \mu \mathrm{l}$ formic acid (70\%) and $70 \mathrm{mg}$ of cyanogen bromide added. The mixture was left overnight 
in the dark at room temperature, then dried, redissolved in $30 \%$ acetic acid and applied to a column of Sephadex G50 (superfine, $115 \times 1 \mathrm{~cm}$ ) equilibrated with $30 \%$ acetic acid. One $\mathrm{ml}$ fractions were collected with a flow-rate of 3.3 $\mathrm{ml} \times \mathrm{h}^{-1}$.

\subsection{Digestion with trypsin}

The largest cyanogen bromide fragment (2.2 $\mathrm{mg}$ ) was acetylated at pH 8.0 in $0.6 \mathrm{M}$-ammoniumbicarbonate by addition of $4 \times 25 \mu$ acetic anhydride with intervals of $10 \mathrm{~min}$. After freezedrying the derivative was redissolved in 0.1 M-ethylmorpholine buffer, $\mathrm{pH} 8.0$ and trypsin (treated with diphenylcarbamylchloride) was added in a ratio of $1: 100(\mathrm{~W} / \mathrm{W})$. After 4.5 hours at $40{ }^{\circ} \mathrm{C}$ the digest was applied to a Sephadex G50 column and eluted as described in section 2.8 .

\subsection{Digestion with carboxypeptidase}

Pertinent peptides were digested with carboxypeptidase $\mathrm{Y}$ and $\mathrm{B}$ in $0.1 \mathrm{M}-\mathrm{N}$-ethylmorpholine buffer, $\mathrm{pH} 7$ or 5.5, aliquots were withdrawn at suitable time-intervals, acidified, dried and finally applied to the amino acid analyser in a buffer at $\mathrm{pH} 2.2$.

\subsection{Separation of peptides by HPLC}

Peptide mixtures were separated on a $\mathrm{C}_{18}$ reverse phase column (Waters) using a gradient of n-propanol in $0.1 \%$ trifluoro-acetic acid.

\subsection{Reactive site cleavage}

Attempts to identify the reactive site(s) of VSI by cleavage with catalytic amounts of subtilisin Carlsberg at $\mathrm{pH} 4.5$ were made as described for the barley CI inhibitors (6). Cleavage with about 2 mole\% porcine pancreas elastase was made in $0.1 \mathrm{M}$-ammonium acetate buffer, $\mathrm{pH} 5.5$, for 24 hours at $25{ }^{\circ} \mathrm{C}$. After freeze-drying the incubation mixture was applied directly to the sequencer.

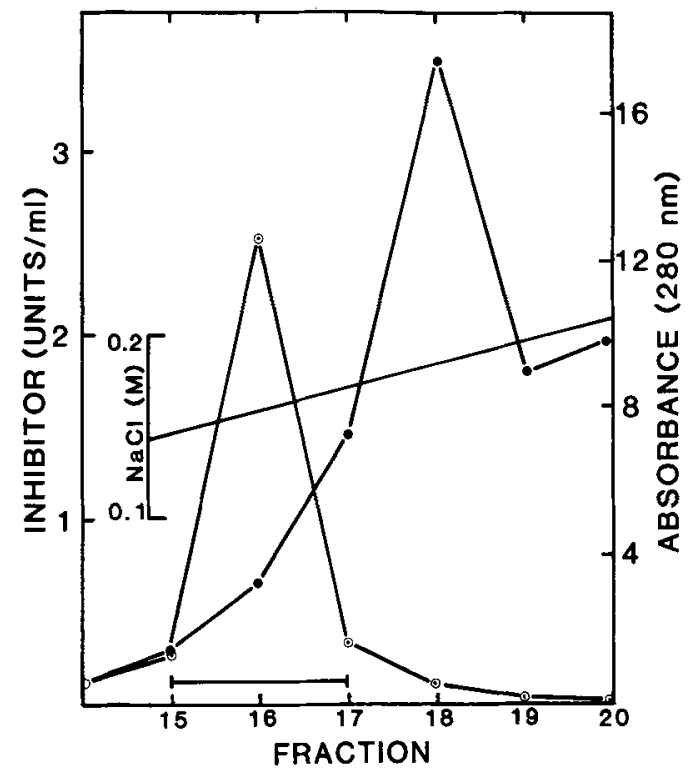

Figure 1. Purification of VSI by anion exchange chromatography at $\mathrm{pH}$ 8.5. Subtilisin inhibitor activity from ammonium sulfate precipitation (section 2.3) was chromatographed on a column of DEAE-Sephadex (section 2.4.1). Absorbance at $280 \mathrm{~nm}(-\bullet-)$, and subtilisin inhibitory activity (--O--) were measured in the collected $20 \mathrm{ml}$ fractions. A bar indicates material pooled for further purification by gel filtration (section 2.4.2 and Figure 2).

\section{RESULTS}

\subsection{Purification}

The crude extract contained 140 units of inhibitor corresponding to about $0.15 \mathrm{mg} \times \mathrm{g}^{-1}$ seed. More than $80 \%$ of the activity was recovered after ammonium sulfate precipitation (section 2.3). In the first chromatographic step, anion exchange at $\mathrm{pH} 8.6$, the inhibitor activity eluted at about $0.16 \mathrm{M}-\mathrm{NaCl}$ in the gradient in front of the major protein peaks (Figure 1). Gelfiltration on a column of Sephadex G50 further separated the inhibitor from a major peak of proteins with higher MW (Figure 2). When the pooled active material was subjected to anion exchange at $\mathrm{pH} 7.5$ (section 2.4.3), the inhibitor activity was eluted in an almost symmetrical peak overlapping with a distinct protein peak at about $0.1 \mathrm{M}-\mathrm{NaCl}$ in the gradient. The pooled material $(14 \mathrm{mg}$ ) constitutes the purified inhibitor (VSI) characterized below and corresponds to a recovery of about $37 \%$ with an 


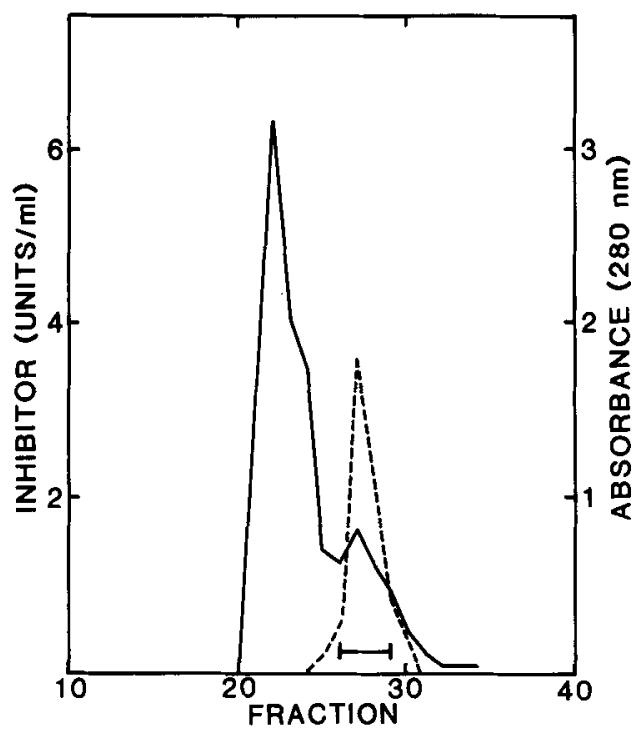

Figure 2. Purification of VSI by gel filtration. Subtilisin inhibitor activity from anion exchange chromatography pH 8.5 (section 2.4 .I and Figure 1) was chromatographed on a column of Sephadex G50 (section 2.4.2). Absorbance at $280 \mathrm{~nm}(-)$ and subtilisin inhibitory activity (----) were measured in the collected $9.5 \mathrm{ml}$ fractions. A bar indicates fractions pooled for further purification by anion exchange chromatography at $\mathrm{pH} 7.5$ (section 2.4.3).

1100-fold purification. In analytical gel fiitration experiments on a long column of Sephadex G75 (section 2.4.4) with 3-4 mg samples of the purified material a symmetrical peak containing all the applied protein and activity was eluted and no increase in the specific activity was obtained.

\subsection{Physico-chemical properties}

The purity of VSI was controlled by PAGEIEF and SDS-PAGE (Figure 3). Protein staining after IEF showed one major band with $\mathrm{pI}=4.8$ and a minor band with $\mathrm{pl}=5.0$ (Figure $3 \mathrm{~A}$ ). Staining for inhibition of subtilisin showed the same bands (Figure 3B), but no trypsin or chymotrypsin inhibitor zones could be detected (Figure 3C). In SDS-PAGE the same pattern of one major and one minor band was detected (Figure 3D). The major band migrated corresponding to a MW near 11,000 , the minor band near MW 8,500, but values obtained for proteins

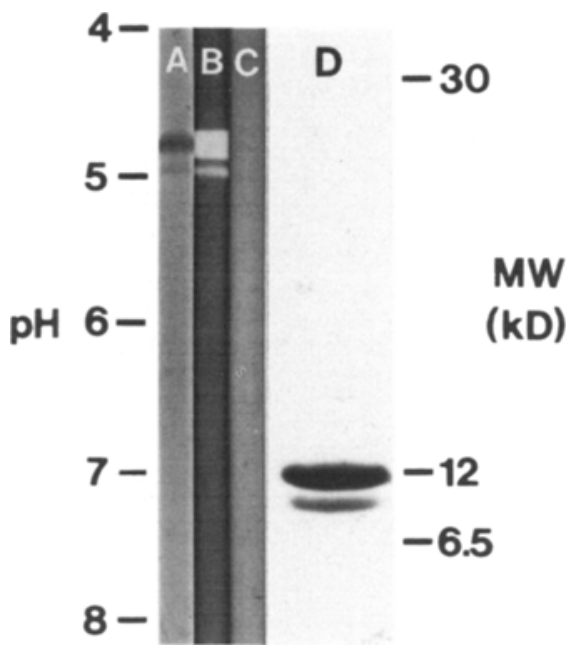

Figure 3. Isoelectric focusing (A-C) and SDS-gel electrophoresis (D) of VSI. About $5 \mu \mathrm{g}$ VSI was applied in IEF. After focusing the gel was stained for protein (A), subtilisin inhibitor activity (B), and trypsin inhibitor activity (C). A pH scale obtained from $\mathrm{pH}$ measurements on eluted $5 \mathrm{~mm}$ sections of a reference gel is included. About $10 \mu \mathrm{g}$ VSI was applied in SDS-PAGE, and after electrophoresis the gel was stained for protein (D). Standardization was made with (from top): Carbonic anhydrase (MW 30,000). cytochrome C (MW 12.000), and aprotinin (MW 6.500).

of this size are not always reliable (1). The result is, however, in general agreement with a MW near 10,500 obtained in repeated gel filtration experiments (section 2.4.4). In addition to the major inhibitor, the VSI preparation, apparently, contains a minor subtilisin inhibitor with a slightly lower MW, but non-active contaminants could not be detected. The amino acid composition of VSI obtained after 24 hours hydrolysis is given i Table I. Comparison with compositions of the Vigna and Phaseolus inhibitors, which are of the same molecular size (15, 20), confirms a high degree of similarity (Table I). The very low cysteine content of especially the Vicia and Vigna inhibitors is characteristic for members of the "potato inhibitor I family" (16).

\subsection{Specificity of inhibition}

Inhibition studies showed that VSI is a strong and relatively specific inhibitor of microbial alkaline proteases. Titration of subtilisin Novo 
Table I.

Amino acid composition of VSI ${ }^{1}$ and comparison with subtilisin inhibitors from Vigna unguiculata (20) and Phaseolus vulgaris (15) ${ }^{2}$.

\begin{tabular}{lccc}
\hline & $\begin{array}{c}\text { Vicia } \\
\text { faba }\end{array}$ & $\begin{array}{l}\text { Vigna } \\
\text { unguiculata }\end{array}$ & $\begin{array}{l}\text { Phaseolus } \\
\text { vulgaris }\end{array}$ \\
\hline Asp & 5.2 & 8.3 & 7.0 \\
Thr & 4.6 & 7.0 & 6.6 \\
Ser & 4.1 & 5.3 & 5.0 \\
Glu & 11.9 & 13.0 & 10.7 \\
Pro & 6.2 & 4.5 & 5.9 \\
Gly & 5.3 & 5.0 & 4.3 \\
Ala & 7.5 & 7.6 & 6.1 \\
Val & 11.2 & 7.1 & 8.1 \\
Met & 0.2 & 2.6 & 1.3 \\
Ile & 3.1 & 2.5 & 4.2 \\
Leu & 2.6 & 3.1 & 3.2 \\
Tyr & 2.0 & 1.6 & 1.7 \\
Phe & 2.0 & 1.2 & 2.7 \\
His & 1.1 & 1.1 & 0.6 \\
Lys & 7.5 & 5.3 & 5.7 \\
Arg & 4.3 & 3.0 & 3.1 \\
l/2 Cys & 0.0 & 0.6 & 3.4 \\
Trp & $(1)^{3}$ & 1.4 & 0.7 \\
\hline
\end{tabular}

1. Values for VSI are from a 24 hours hydrolysis, only.

2. To obtain a MW near 9,000 , all three proteins were assumed to contain 80 residues in these recalculations.

3. Trp was not determined, but 1 Trp was found during sequencing.

and subtilisin Carlsberg $\left(4 \times 10^{-7} \mathrm{M}\right)$ with VSI proceeded linearly to almost $100 \%$ inhibition, therefore the data obtained did not allow for an estimation of $\mathrm{K}_{\mathrm{i}}$ values according to the method of GREEN and WORK (3). In similar experiments with technical grade preparations of alkaline proteases from Aspergillus oryzae and Bacillus pumilus the inhibition curve was linear up to at least $90 \%$ inhibition.

In contrast to the previously sequenced members of this inhibitor family, VSI did not inhibit chymotrypsin. A weak "non-stoichiometric" inhibition of pancreas elastase was found after $5 \mathrm{~min}$ preincubation, but the enzyme activity was partially released during the assay. In experiments where VSI was preincubated with elastase for $30 \mathrm{~min}$ prior to addition of substrate, no inhibition of pancreas elastase could be detected. Apparently, inhibition was of the "temporary" type first described by LASKOWSKI and WU (8). No interaction of VSI with trypsin was observed.

\subsection{Amino acid sequence}

\subsubsection{Terminal sequences}

An attempt to determine the amino acid sequence directly from the $\mathrm{N}$-terminal failed due to blockage of the N-terminal residue. Treatment of the inhibitor with pyroglutamic acid decarboxylase did not liberate any new N-terminal amino acid which excludes pyroglutamic acid as the $\mathrm{N}$-terminal. A peptide which amounted to approximately $7 \%$ of the material applied to the sequencer could, however, be followed 12 steps, giving the sequence: Val-GluGlu-Lys-Ala-Glu- X -Leu-Thr- X -Pro-Asp-.

The electrophoretic characterization (Figure 3) showed no presence of contaminating non-active proteins, and no "background" sequences were detected in the subsequent sequencing of inhibitor fragments (sections 3.4.2 and 3.4.3). These observations suggest that the above sequence represents the $\mathrm{N}$-terminus of the minor component detected by IEF and SDS-PAGE, and also that this inhibitor represents a molecular form of the same protein as the major component, but with a partially degraded $\mathrm{N}$-terminus. This interpretation is in accordance with experiences from sequencing of the homologous barley CI-2 inhibitor, where both an inhibitor with blocked N-terminus and molecular forms with "ragged" N-termini were identified (17).

Attempts to determine the carboxyl terminal sequence by digestion with carboxypeptidase $Y$ in the presence of $0.5 \%$ SDS (16) or with carboxypeptidase B were unsuccessful.

\subsubsection{Cyanogen bromide fragments}

Since the amino acid analysis(Table I) showed the presence of methionine $(0.2 \mathrm{~mol} / \mathrm{mol}$ of inhibitor) the inhibitor was treated with cyanogen bromide followed by gel filtration on Sepha$\operatorname{dex}$ G50. The elution pattern showed two major peaks. The peak representing the largest molecular weight contained $80 \%$ of the treated material and showed to be uncleaved VSI with blocked $\mathrm{N}$-terminal, but a minor peptide gave 
-Arg-Thr-Ser-Trp-Pro-Glu-Leu-Val-Gly-Val-Ser-Ala-Glu-Glu-Ala-Arg-Lys-Ile-Lys-Glu-Glu

30

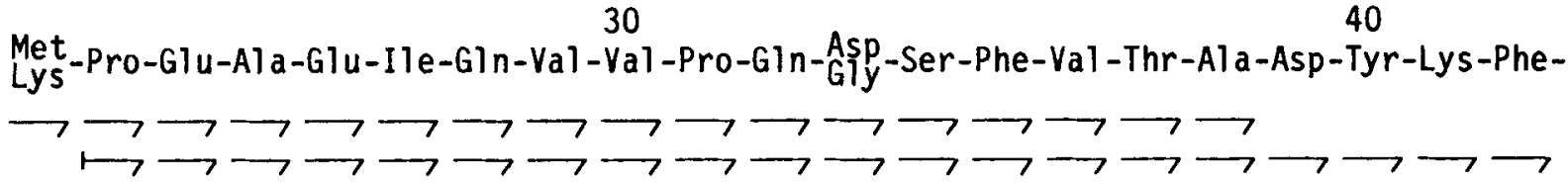

50

60

Gln-Arg-Val-Arg-Leu-Tyr-Val-Asp-Glu-Ser-Asn-Lys-Val-Val-Arg(Ala, Ala, Pro) Ile-Gly

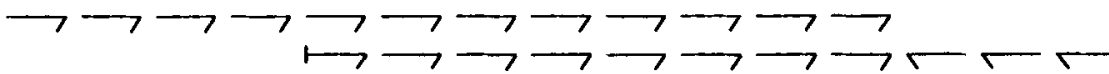

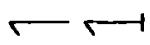

Figure 4. Partial amino acid sequence of VSI. $\longmapsto$ indicates start and direction of sequencing by automatic Edman degradation. $\neg-$ cleavage with carboxypeptidase $Y$.

the same $\mathrm{N}$-terminal as described in section 3.4.1. The second smaller peak contained a peptide beginning: Pro-Glu-Ala- and it was sequenced 32 steps $\left(\right.$ Pro $_{23}-$ Lys $_{54}$ in Figure 4). However, the amino acid composition of this peak material was compatible with that of the inhibitor itself. Furthermore, the peptide observed in limited amounts in the unmodified VSI was also detected in this sequencer run. Apparently, two peptides of approximately equal length were eluted in the second peak, one of which represented the blocked N-terminal of VSI. The cleavage of $20 \%$ of VSI with cyanogen bromide is compatible with a content of 0.2 mole Met/mole of VSI (Table I) and indicates polymorphism of the inhibitor.

\subsubsection{Tryptic peptides}

Acetylated VSI was digested with trypsin and the peptides were separated by gel filtration on Sephadex G50. Two peaks detected from measurement of $\mathrm{OD}_{280}$ (A and $\mathrm{B}$ ) were followed by two peptide peaks (C and D), identified only by spot test for Arg. The front peak $\mathrm{A}$ was sequenced 22 steps starting with Lys (Figure $_{17}$ 4). A Lys was identified in step 6, an observation not compatible with Met in position 22 as deduced from the cyanogen bromide sequence (section 3.4.2). Furthermore, Asp was identified in step 17 (position 33) which was occupied by a Gly in the overlapping cyanogen bromide fragment. The most plausible explanation of these findings appears to be that at least two genetic variants of VSI are present in the preparation: One containing the residues $\mathrm{Arg}_{16}, \mathrm{Lys}_{22}$, and $\mathrm{Asp}_{33}$, while the other molecular form with Met $_{22}$ and Gly $_{33}$ may contain another residue $\mathrm{X}_{16}$, not allowing for tryptic cleavage.

The second peak $B$ from the gelfiltration contained two peptides with free terminals. One peptide started with Leu $_{47}$ (Figure 4) and disappeared after eight steps at the same position as the cyanogen bromide fragment. The second peptide was followed 14 steps. Comparison with sequences of inhibitors from the same family (Figure 5) shows that this peptide corresponds to residues $\mathrm{Thr}_{2}-\mathrm{Ala}_{15}$ in Figure 4. The precedent residue must be $\mathrm{Arg}_{i}$, since the acetylated lysines were unaccessible to trypsin.

Separation of the peak B material by HPLC resulted in isolation of three major peptides (B-5, B-6 and B-10). Digestion of peptide B-5 with carboxypeptidase $\mathrm{Y}$ liberated Val and Arg in the molar ratio $2: 1$. With this information the amino acid composition of B-5 (Table II) is compatible with the peptide previously sequenced from position $47\left(\mathrm{Leu}_{47}-\mathrm{Arg}_{57}\right)$. Although this peptide contains three Val, while only two residues were found by amino acid analysis, it is well-known that a Val-Val sequence drastically decreases the rate of Val released during hydrolysis in $6 \mathrm{M}-\mathrm{HCl}$. The amino acid composition of the peptide B-10 
Table II. Amino acid composition of tryptic peptides from VSI separated by HPLC.

\begin{tabular}{|c|c|c|c|c|c|c|}
\hline $\begin{array}{l}\text { Amin } \\
\text { acid }\end{array}$ & B-5 & B-6 & B- 10 & D-2 & D-4 & D-7 \\
\hline Asp & $1.8(2)$ & $1.1(1)$ & - & & & \\
\hline Thr & & $0.9(1)$ & $1.1(1)$ & & & \\
\hline Ser & $1.1(1)$ & $2.0(2)$ & $2.1(2)$ & & & \\
\hline Glu & $1.4(1)$ & $2.4(2)$ & $2.9(3)$ & & & $1.3(1)$ \\
\hline Pro & & $1.1(1)$ & $0.8(1)$ & & $1.2(1)$ & \\
\hline Gly & & $1.1(1)$ & $1.5(1)$ & & $1.0(1)$ & \\
\hline Ala & & $1.0(1)$ & $1.9(2)$ & & $2.0(2)$ & \\
\hline Val & $2.0(2)$ & $1.1(1)$ & $1.6(2)$ & $1.0(1)$ & & \\
\hline Ile & & $0.5(0-1)$ & & & $1.2(1)$ & \\
\hline Leu & $1.0(1)$ & $1.0(1)$ & $1.4(1)$ & & & \\
\hline Tyr & $1.2(1)$ & & & & & \\
\hline Phe & & & & & & $0.7(1)$ \\
\hline Lys & $0.9(1)$ & $0.5(0-1)$ & & & & $1.0(1)$ \\
\hline Arg & $0.9(1)$ & $0.8(1)$ & $0.9(1)$ & $1.0(1)$ & & $0.9(1)$ \\
\hline
\end{tabular}

(Table II) is compatible with the other sequenced peptide $\left(\mathrm{Thr}_{2}-\mathrm{Arg}_{16}\right)$. The composition of the third major peptide B-6 (Table II) derived from peak B does not cover any of the sequences determined so far. However, only two N-terminal sequences were detected when the peak $B$ peptide mixture was sequenced and therefore peptide B-6 most likely represents the 12-14 $\mathrm{N}$-terminal residues of VSI. The amino acid composition of B-6 agrees fairly well with the minor sequence obtained by direct sequencing of the VSI preparation (section 3.4.1) but since overlap between this sequence and the sequence starting at $\mathrm{Arg}_{1}$ (Figure 4) was not established the final proof is lacking.

One of the peaks located by Arg spot test (peak D) was separated into three small peptides by HPLC. The amino acid composition of the dipeptide D-2 (Table II) is compatible with $\mathrm{Val}_{45}-\mathrm{Arg}_{46}$ (Figure 4), and peptide D-7 with

VSI (broad bean)
CI-2 (barley)
CI-1 (barley)
PI-I (potato)
LIE (leech)

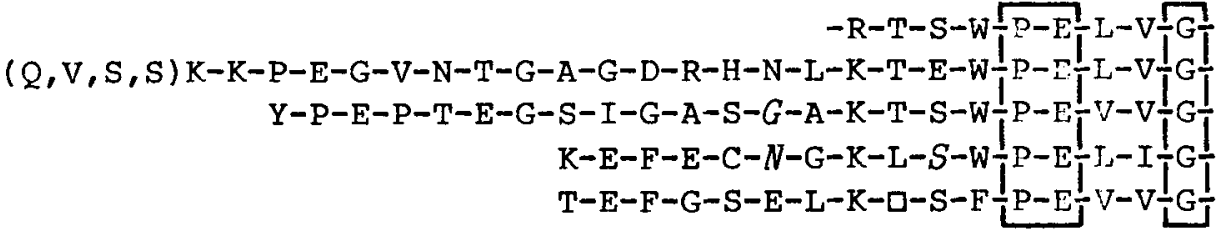

VSI (broad bean)
CI-2 (barley)
CI-I (barley)
PI-I (potato)
LIE (leech)

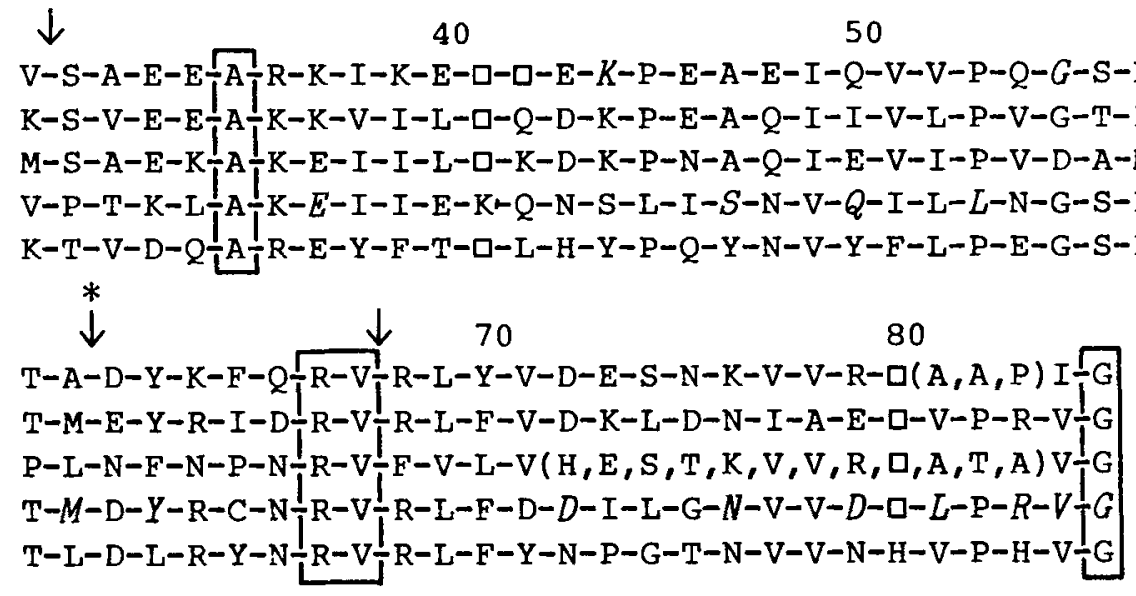

VSI (broad bean)

CI-2 (barley)

CI-1 (barley)

PI-I (potato)

LIE (leech)

Figure 5. Comparison af amino acid sequences of inhibitors from the "potato inhibitor I family". The partial sequence of VSI (Figure 4) is compared with sequences of: Barley inhibitors Cl-1 and CI-2 $(16,17,18)$ potato inhibitor I (12) and the leech inhibitor eglin (13). For the discussion the VSI sequence (Figure 4) has been renumbered in accordance with previous comparisons (16). One letter codes in italics indicates positions where polymorphisms have been identified. Arrows indicate bonds in VSI split by pancreas elastase. An asterisk indicates the major reactive site bond identified in the previously sequenced inhibitors. Invariant amino acids are boxed. $\square$ indicates gaps introduced to maximize homology. 
$\mathrm{Lys}_{41}-\mathrm{Arg}_{44}$, assuming an unspecific cleavage after $\mathrm{Tyr}_{40}$. The third peptide D-4 has a composition different from the part of the sequence discussed so far, and since the peptide does not contain Arg, it might represent the C-terminal part of the inhibitor. Digestion with carboxypeptidase $\mathrm{Y}$ liberated Gly and Ile in equal amounts which indicates that Gly is the C-terminal amino acid of the peptide (Figure 4). All the previously sequenced peptides of the family have a Gly in the C-terminal position (Figure 5), and the size of peptide D-4 exactly corresponds to the remaining gap in the sequence. Thus, the total composition of the sequenced part (Figure 4) plus the proposed $\mathrm{N}$-terminal peptide B-6 agrees fairly well with the composition of VSI presented in Table I, except for the single His, which was not observed in any of the sequenced steps.

\subsection{Reactive site(s)}

Calculations from the inhibition experiments with subtilisins (section 3.3) showed a molar ratio of $1: 1$ in the complex formed. Reactive sites in other inhibitors have been identified by cleavage at low $\mathrm{pH}$ with catalytic amounts of the enzyme inhibited $(6,7,11,13,14,15)$. Attempts to identify a reactive site for subtilisin Carlsberg by this technique were, however, unsuccessful. The "temporary" inhibition of pancreas elastase suggested a proteolytic modification of VSI by this enzyme (section 3.3). When VSI was treated with elastase in similar experiments and applied to the sequencer directly after incubation, a mixture of three peptides in almost equal quantities could be identified as: $\operatorname{Ser}_{11}-\mathrm{Ala}_{12}-\mathrm{Glu}_{13}-\mathrm{Glu}_{14}-\mathrm{Ala}_{15^{-}}$, Asp $_{39}-\mathrm{Tyr}_{40}-\mathrm{Lys}_{41}-\mathrm{Phe}_{42^{-}}$, and $\mathrm{Arg}_{46}-\mathrm{Leu}_{47}-\mathrm{Tyr}_{48^{-}}$ $\mathrm{Val}_{49}-\mathrm{Asp}_{50^{-}}$(Figure 4). The cleavage of the three bonds $\mathrm{Val}_{10}-\mathrm{Ser}_{11}, \mathrm{Ala}_{38}-\mathrm{Asp}_{39}$ and $\mathrm{Val}_{45}-\mathrm{Arg}_{46}$ is in accordance with the specificity of elastase.

\section{DISCUSSION}

Although the N-terminal sequence of VSI was not determined, comparisons clearly confirm that VSI belong to the "potato inhibitor I family" of homologous inhibitors (7). In the comparable part of the sequences (residues 21-71, Figure 5) $56 \%, 46 \%, 42 \%$, and $36 \%$ of the residues in
VSI were found in the same positions as in $\mathrm{Cl}-2$, Cl-1, PI-I and LIE, respectively. The similar amino acid compositions (Table I) and isoelectric patterns (2) strongly suggest that inhibitors of this family are widespread in seeds of leguminous plants. The wide distribution in the plant kingdom and the homology with the animal inhibitor leech eglin may suggest a universal distribution.

Previously sequenced inhibitors were present in a number of molecular forms due to both genetic variants and "ragged" $N$-terminals, and during purification it was difficult to separate them completely $(1,16,17)$. Similar observations were made during the present study. Although VSI was isolated in an apparently pure form, the preparation contained the same mixture of one major and one minor form as the crude extract (2). The major form had a blocked $\mathrm{N}$-terminal, as one of the barley $\mathrm{Cl}-2$ inhibitors $(17,18)$, and at least two genetic variants were detected. Only monomer forms of VSI were detected during purification, in contrast to the strong tendency of the barley and potato inhibitors to form dimer and/or tetramer aggregates $(1,10,11)$.

The major cleavage point for chymotrypsin and/or subtilisin, which is assumed to represent the reactive site $P_{1}-P_{i}^{\prime}$ bond, was identified in the same position between residues 60 and 61 (Figure 5 ) in all the four previously sequenced inhibitors $(6,11,13)$. They all have a large hydrophobic amino acid $\left(\mathrm{Met}_{60}\right.$ or $\left.\mathrm{Leu}_{60}\right)$ in the $\mathbf{P}_{1}$ position. The presence of $\mathrm{Ala}_{60}$ in VSI may explain why VSI is not reacting with chymotrypsin, but still is a strong inhibitor of subtilisins. This finding also suggests a specificity for elastases (7), but only a weak "non-stoichiometric" inhibition of porcine pancreas elastase was found. Ala was also detected in the assumed $P_{1}$ position of the Phaseolus inhibitor $(14,15)$, which was a strong inhibitor of both subtilisin and leukocyte elastase, but the latter enzyme was not included in the present study.

The assumed reactive site bond $\mathrm{Ala}_{60}-\mathrm{Asp}_{61}$ was among the three sites in VSI cleaved by catalytic amounts of pancreas elastase. One of the other cleavage points was at $\mathrm{Val}_{30}-\mathrm{Ser}_{31}$ (Figure 5). Cleavage in barley inhibitor Cl-1 (6) with catalytic amounts of subtilisin suggested 
Met $_{30}-$ Ser $_{31}$ as a second subtilisin reactive site. The amino acid sequence around this position seems to be highly conserved, but whether it is a truely inhibitory binding site remains to be resolved. The present inhibition studies suggested a molar ratio of $1: 1$ in the VSI-subtilisin complex. The third elastase sensitive bond at $\mathrm{Val}_{67}-\mathrm{Arg}_{68}$ is close to the assumed binding site at Ala $_{60}-$ Asp $_{61}$. Cleavage at this position may explain why VSI only functions as a temporary inhibitor of pancreas elastase.

\section{ACKNOWLEDGEMENTS}

The expert assistance of Mss. BODIL CORNELIUSSEN and LONE SøRENSEN is gratefully acknowledged.

\section{REFERENCES}

1. Boisen. S.. C. Yding Andersen \& J. HejgaArd: Inhibitors of chymotrypsin and microbial serine proteases in barley grains. Isolation, partial characterization and immunochemical relationships of multiple molecular forms. Physiol. Plant. 52, 167 176 (1981)

2. Chavan, J.K. \& J. HejgaARD: Detection and partial characterisation of subtilisin inhibitors in legume seeds by isoelectric focusing. J. Sci. Food Agric. 32, 857-862 (1981)

3. Green. N.M. \& E. Work: Pancreatic trypsin inhibitor. 2. Reaction with trypsin. Biochem. J. 54, 347-352 (1953)

4. HiRS. C.H.W.: Determination of cystine as cysteic acid. Methods Enzymol. 11, 59-62 (1967)

5. Johansen, J.T., C. Overballe-Petersen, B. Martin, V. Hasemann \& I. SVEndSEn: The complete amino acid sequence of copper, zink superoxide dismutase from Saccharomyces cerevisiae. Carlsberg Res. Commun. 44, $201-217$ (1979)

6. JONASSEN, I. \& I. SVENDSEN: Identification of the reactive sites in two homologous serine proteinase inhibitors isolated from barley. Carlsberg Res. Commun. 47, 199-202 (1982)

7. Laskowski. JR., M. \& I. Kato: Protein inhibitors of proteinases. Ann. Rev. Biochem. 49, 593-626 (1980)

8. LASKOWSKI. JR... M. \& F.C. WU: Temporary inhibition of trypsin. J. Biol. Chem. 204, 797-805 (1953)
9. LyUblinskaya, L.A. S.V. Belyaev, A.YA. Strongin, L.F. Matyash, E.D. Levin \& V.M. STEPANOV: A new chromogenic substrate for subtilisin. Anal. Biochem. 62, 371-376 (1974)

10. Mikola. J. \& E.-M. Soulinna: Purification and properties of an inhibitor of microbial alkaline proteinases from barley. Arch. Biochem. Biophys. 144. 566-575 (1971)

11. RichaRdson, M., R.D.J. BarkeR, R.T. MCMILL.AN \& L.M. Cossins: Identification of the reactive (inhibitory) sites of chymotrypsin inhibitor I from potatoes. Phytochemistry 16, 837-839 (1977)

12. Richardson, M. \& L. Cossins: Chymotryptic inhibitor I from potatoes: The amino acid sequences of subunits B, C, and D. FEBS Lett. 45, 11-13 (1974). (Corrigendum in FEBS Lett. 52, 161 (1975)

13. SeEmúller, U., M. Eulitz, H. Fritz \& A. Strobl: Structure of the elastase-cathepsin $G$ inhibitor of the Leech Hirudo medicinalis. Hoppe-Seyler's Z. Physiol. Chem. 361, 1841-1846 (1980)

14. SEIDL, D.S.. H. AbReU \& W.G. Jaffe: Purification of a subtilisin inhibitor from black bean seeds. FEBS Lett. 92, 245-250 (1978)

15. Seidl. D.S.. H. Abreu \& W.G. JafFe: Partial characterization of a substilisin inhibitor from black bean seeds. Int. J. Peptide Protein Res. 19, 153-157 (1982)

16. Svendsen, I.. S. Boisen \& J. HejgaArd: Amino acid sequence of serine protease inhibitor $\mathrm{Cl}-1$ from barley. Homology with barley inhibitor $\mathrm{CI}-2$, potato inhibitor I, and leech eglin. Carlsberg Res. Commun. 47, 45-53 (1982)

17. SVEndsen, I. I. Jonassen. J. HejgaARd \& S. BoISEN: Amino acid sequence homology between a serine protease inhibitor from barley and potato inhibitor I. Carlsberg Res. Commun. 45, 389-395 (1980)

18. SVEndSen, I..B. Martin \& I.Jonassen: Characteristics of Hiproly barley III. Amino acid sequences of two lysine-rich proteins. Carlsberg Res. Commun. 45, 79-85 (1980)

19. VARTak. H.G. A.M. Bodhe. S.V. Paranjpe \& V. JAGANNathan: Proteinase inhibitors from Vigna unguiculata subsp. cylindrica. II. Inhibitors of subtilisin and trypsin. Arch. Biochem. Biophys. 204, 129-133 (1980)

20. Vartak, H.G., M.V. Rele \& V. JaGannathan: Proteinase inhibitors from Vigna unguiculata subsp. cylindrica. III. Properties and kinetics of inhibitors of papain, subtilisin and trypsin. Arch. Biochem. Biophys. 204, 134-140 (1980) 